\title{
INTERNATIONAL ASPECTS OF STATE REGULATION OF SOCIO-ECONOMIC RESPONSIBILITY OF ENTREPRENEURSHIP: EXPERIENCE FOR UKRAINE
}

\author{
Ludmila Batchenko' \\ Kyiv National University of Culture and Arts, Ukraine \\ Maryna Dielini² \\ National Pedagogical Dragomanov University, Ukraine
}

\begin{abstract}
The subject of the study is the socio-economic aspects of the social responsibility of business (CSR) in 4 countries. The purpose of the article is to study the experience in regulating the socio-economic responsibility of entrepreneurship in the United States, Sweden, India, and China to determine the direction of formation of the state mechanism of socio-economic responsibility of entrepreneurship (SERE) in Ukraine. The methodology of the article became theoretical researches of foreign scientists, their synthesis, systematization, and analysis for the development of the application of experience in Ukrainian realities. The analysis showed how different states of CSR policy differ in each of these countries and made it possible to draw conclusions about the application in Ukraine. So, the experience of Sweden is useful in reviewing the social reporting obligation, as well as the experience of China. In the case of the USA, the role of the state in regulating CSRs in enterprises should be noted but, at the same time, the significant social consciousness of American entrepreneurs as recognized philanthropists, who are actively introducing ethical codes and key stewards from the implementation of CSR, are seen by society and aimed at improving the well-being of society. In China, the government plays an important role in the implementation of CSR for state-owned enterprises. In addition, laws are adopted to improve the rights of employees, to equalize gender differences, to increase the level of production, quality of products, which leads to an improvement in the quality of life of the country's population. All this becomes relevant for Ukraine and can be used in our country as well. Indian experience draws attention through the adoption of a unique decision on the indifference of charity activities by Indian companies with a certain level of profit and the adoption of them by the rules of corporate social responsibility. In entrepreneurship, these measures have not received support and a large number of enterprises artificially lower their profits. Also, the problem of effective reform of Indian social responsibility is the high level of corruption in the state, as well as the ineffectiveness of the current legislation. Taking into account all these disadvantages when developing its own policy of developing social and corporate responsibility of business, Ukraine is able to build a strong and effective mechanism of a socially responsible society. For the Ukrainian realities, the following areas are emphasized: the approval of the obligation of social reporting for large enterprises of all forms of ownership and state enterprises in general, the improvement of Ukrainian legislation in the field of social responsibility of business, the study of the possibility of introducing the obligation of charity for large enterprises from different sides (that is, how this will affect society, how it will affect the work of enterprises, how can it be regulated by law, what kind of reaction this will cause in society); conducting of informational and consulting measures by the Government of Ukraine for the dissemination of knowledge, skills, competences for the implementation and implementation of socio-economic responsibility at Ukrainian enterprises.
\end{abstract}

Key words: social responsibility of business, socio-economic responsibility of entrepreneurship, charity, philanthropy, social reporting.

JEL Classification: M21, M41, L30, F20

\footnotetext{
Corresponding author:

${ }^{1}$ Department of Hotel and Restaurant Business, Kyiv National University of Culture and Arts.

E-mail: ludavic@meta.ua

${ }^{2}$ Department of Management, Information and Analytical Activity and European Integration, National Pedagogical Dragomanov University.

E-mail: marina.dielini@gmail.com
} 


\section{Introduction}

In the modern world, social responsibility of business is an important element of the functioning of any enterprise, providing opportunities for effective business development. The socio-economic aspect of social responsibility manifests itself in the application of economic levers for its realization. In other works of authors, the basic forms and tools of socio-economic responsibility of entrepreneurship were given. In this research, we study the experience of two developed countries (the USA and Sweden) and two Asian countries (China and India) that are actively developing their economies. The experience of these countries will be useful to Ukraine to build a solid system of socioeconomic responsibility of business. The purpose of the article is to study the experience of regulating the socioeconomic responsibility of the state of the USA, Sweden, China, and India in developing the areas of stifling in Ukraine and building a functioning mechanism of socio-economic responsibility of entrepreneurship. The methodology of the article was the systematization, synthesis, and analysis of theoretical studies on the subject of the research. The work gradually reveals the essence of state policy in the developed countries: the USA and Sweden, and then we turn to the experience of China and India, after which the possibility of using one or another measures in Ukrainian realities is analysed.

\section{Sweden's and the USA's experience in the regulation of SERE}

First, we will research the experience of Sweden and the United States, countries with a developed economy, in which CSR has been developing for a long time and occupy a significant place in the activities of enterprises.

Sweden is traditionally considered a country with a social economy and therefore the system of social responsibility in it is set at a high level. In this study, we will also consider the main elements that can be attributed to socio-economic responsibility.

Turning to figures, we can present the following achievements of Sweden, which are recognized by the world community:

1. 2007 - Sweden topped the Responsible Competitiveness Index. This index was based on a range of parameters covering climate, working environment, corruption and social issues among companies in 108 countries. In particular, the report highlighted gender equality in Sweden.

2. 2010 - Climate Competitiveness Index 2010 acknowledges the Nordic countries to be in the forefront of combating climate change and promoting the development of "cleantech," an umbrella term for innovations that reduce emissions or energy consumption.

3. 2010 - World Economic Forum's Global Gender Gap Report 2010 states that Sweden and the other
Nordic countries "emerge as top performers and true leaders on gender equality ... and thus serve as models and useful benchmarks for international comparisons." (Sweden leads by example in corporate responsibility).

CSR in Sweden is a part of the industrial policy, which objective is to strengthen competitiveness and create more jobs and growing companies. The issues of the Swedish Parliament linked to CSR include human rights, decent working conditions, environmental considerations and anti-corruption efforts, as well as gender equality, diversity, business ethics, and taxation. All of them are interconnected with SERE as they have an economic base and as well some of them is a direct economic tool that influences business and society (The Swedish Government policy for corporate social responsibility).

In Table 1, the main developments of Sweden's CSR are presented.

So, do we see that some measures are being taken by the government in Sweden that increasing the level of SERE, and namely: the obligatory social reporting of state-owned enterprises, the adoption of laws that regulate the economic instruments of SERE, the implementation of measures for the spread of social responsibility among the private sector.

Now we will turn to the experience of the United States, a country with almost the largest history of using such a tool of SERE as a philanthropy and charity. The US refers to the American model of CSR, which differs little role of the state in the regulation of social responsibility. Most of the tasks are assigned to the enterprises. But despite this, the US is a country with a developed CSR system and strong social protection for workers and consumers.

It is the tradition to contribute a part of the profits for charity in order to improve the attitude of the local community towards a particular production and has formed an American model of social responsibility. American businessmen are involved in financing a wide variety of non-profit projects, and through this, they solve various social problems (vocational education, pension and social insurance, environmental protection).

The state does not directly interfere in these processes, but only stimulates them through a system of privileges and subsidies.

In particular, the United States introduced tax incentives aimed at helping employers compensate for the cost of hiring disabled people, pensioners, young people, and veterans (Kolosok, 2015).

U.S. businesses face social responsibility. According to the A. Carroll model CSR has 4 dimensions: economic, legal, ethical, and discretionary responsibilities. Discretionary responsibility is defined as the presumption that a company will voluntarily serve society. Such service reaches beyond economic, legal, and even ethical responsibilities. Most businesses support the fight against hunger (Forte, 2013). 
Table 1

The main developments of Sweden's CSR

\begin{tabular}{|c|c|c|c|}
\hline$\#$ & $\begin{array}{c}\text { Sphere of } \\
\text { developments }\end{array}$ & Characteristic & SERE direction \\
\hline 1 & Legislative & $\begin{array}{l}\text { Sweden was the first country ( } 2007) \text { to demand sustainability reports from state- } \\
\text { owned enterprises. The reports have to comply with guidelines from the Global } \\
\text { Reporting Initiative (GRI). }\end{array}$ & $\begin{array}{l}\text { It's a tool of SERE that reflects } \\
\text { main aspects of enterprise's CSR. }\end{array}$ \\
\hline 2 & Administrative & $\begin{array}{l}\text { Since many years the government has made several attempts to encourage and } \\
\text { inspire Swedish companies to engage in strategic CSR. The Ministry for Foreign } \\
\text { Affairs has a platform for dialogue with business, social partners, labour unions and } \\
\text { NGOs working with social responsibility and has during the past years organized } \\
\text { and participated in several seminars about CSR including anti-corruption. } \\
\text { The Swedish International Development Cooperation Agency (Sida), a government } \\
\text { agency, is increasingly working together with the private sector to stimulate } \\
\text { development, innovation, entrepreneurship, and CSR in developing countries. Sida } \\
\text { aims to contribute to the promotion of sustainable and inclusive business practices } \\
\text { through its experience of operating in less explored trade environments. }\end{array}$ & $\begin{array}{l}\text { The development of socially } \\
\text { responsible entrepreneurship } \\
\text { through private sector } \\
\text { conducting seminars, business } \\
\text { cases and so on that can } \\
\text { increase the level of socio- } \\
\text { economic responsibility of } \\
\text { entrepreneurship. }\end{array}$ \\
\hline 3 & Adjudication & $\begin{array}{l}\text { There are specific laws in Sweden, civil and criminal, on health and safety, } \\
\text { equal opportunities, the right of the collective agreement, corruption and } \\
\text { discrimination as well as other human rights-related challenges. }\end{array}$ & $\begin{array}{l}\text { These laws regulate as well } \\
\text { economic base of CSR and } \\
\text { namely: taxation, corruption, } \\
\text { legal business etc. }\end{array}$ \\
\hline
\end{tabular}

Table is built on the base of Overview of CSR developments at the national level

In relation to another SERE instrument - social reporting, it should be noted that in the US it is not regulated by the state, a required framework for reporting does not currently exist, but has a lot of names: "environmental reports", "social reports", "climate change reports", "carbon reports", "triple bottom line reports" and "sustainability reports" among others.

Despite the lack of regulations in the United States requiring companies to disclose, increasingly more and more companies are issuing CSR reports for a variety of reasons. Research suggest that there are three main theories for this increasing trend: (a) to manage the perceptions of key stakeholders, which is explained in signalling theory; (b) to convey the organization's values to the public, which is called impression management theory; and the most widely cited reason (c) to establish that the organization's activities are in line with social norms, which is legitimacy theory. In addition to the organization's motivations for disclosure, there is a growing demand for this nonfinancial information (Cecil, 2008).

Besides, in the USA, it is typical for businesses to list ethics codes and concentrate on the following stakeholder groups - community. The USA entrepreneurs tended to zero in on issues that were not directly connected to their activities. They paid attention to arts, education, culture, and the quality of life. The U.S. firms focused on issues connected to the well-being of the community (Forte, 2013).

Consequently, we see that in the United States, there are some other forms of implementation of SERE philanthropy, the most widespread in this country, tax incentives for the development of SERE and the orientation and development of the community. There are no requirements for providing social reporting though. The US experience can be useful for Ukraine in several directions, which will be further dispersed.

\section{Regulation of SERE in China and India}

First, let us look at the example of China as emerging economies. So, CSR has now become a party to the day in China, but it still remains a problematic issue that is related to the cultural and social factors of China. It should be noted that if before the CSR was inherent by foreign-owned companies operating in the Chinese market, now local companies are introducing CSR as well (Buhmann, 2005).

The fact of increasing priority of Chinese CSR during last years is based on the growing interest in the sustainable development of Chinese society. It is also very important sign due to China's leading position in the worldwide production chain.

In China, CSR is interconnected with "harmonious society" - the concept that is built on the base of Confucius study and aimed to develop stable and harmonic Chinese society (CSR Asia, 2016).

The most significant law provision with respect to CSR is the 2005 amendment to the Company Law. The Company Law, which is the law detailing a general operating framework for companies, refers to general principles of Social Responsibility for companies. The "Harmonious Society" should be achieved thanks to the Scientific Development Concept, which is the current Chinese ideological guidance, and calls for sustainable development and social welfare such as the gap between rural and urban development, unequal income distribution, insufficiency of household wealth, ecological degradation, and lack of efficient use of resources. CSR is also seen as an important component 
of companies' competitiveness, as put forward in the CSR Guidelines for State-Owned Enterprises. Interestingly, CSR is also considered as a driver for corporate innovation (CSR Frameworks in China and the European Union).

Now we can observe the increase in a number of social reports and the development of charitable and volunteer activities (Mullich, 2009).

At the Third Plenary Session of the 18th Central Party Committee on comprehensive reform in November 2013, social responsibility was announced as one of eight focus areas for further reform for Chinese SOEs. In addition, since 2008, state-owned companies have been obliged to publish annual CSR reports. These can be used to start the discussion with state-owned companies about CSR.

The state actively promotes the development of CSR, adopting relevant laws or making changes to existing ones (CSR Frameworks in China and the European Union). List the main laws of the People's Republic of China in the sphere of CSR: Company Law (Amended 2005), Labour Law of the People's Republic of China (1998), Labour Contract Law (2008), Law on the Protection of Rights and Interests of Women (2002), Production Safety Law (2002), Article 26 of the Constitution (1982, amended 1988, 1993), Environmental Protection Law (1989), Law on the Environmental Impact Assessment (2003), Law on the Promotion of Clean Production (2003), Law on Prevention and Control of Water Pollution (1984, amended 2008).

These laws regulate CSR and SERE in particular, including the socio-economic dimension in the field of ensuring employment, rights of workers, production of quality products, etc.

A particular attention for Ukrainian enterprises deserves the experience of operating and regulating the activities of state-owned enterprises: the obligation of their social reporting and a higher level of social responsibility inside the country are observed precisely at state enterprises.

Moving on to the experience of India, which in the sphere of CSR decided to go further than other countries: in 2013, it entered into force Article 135 of the Law "On Companies", which obliges large companies to disclose information about CSR. In addition, India has become the first country in the world to make obligatory charity. Thus, the Law "On Companies" sets mandatory deductions for CSR at a rate of $2 \%$ of the average net profit for the three financial years for companies with either own funds of over 5 billion INR (more than 77 million USD), or a turnover in excess of 10 billion INR (more than 155 million USD), or a net profit of 50 million INR (more than 775 million USD) during the fiscal year (Legislative regulation is intensifying worldwide). From this, we see that it is a socio-economic responsibility that manifests itself when an enterprise uses economic instruments in addition to social actions.
Traditionally, CSR in India was implemented as charity, and it was not discussed by companies, so there were almost no documents on its implementation.

As some observers note, CSR practices in India are still within the charitable space but moved from the institutional framework (educational, research and cultural) to community development through various projects (Handbook on Corporate Social Responsibility in India).

In 2014, the next development of CSR was taken place - the Indian government also adopted the "Corporate Social Responsibility Rules", which, along with Article 135 of the Company Law, are two of the most important documents that provide the legal basis for CSR.

These rules establish a certain list of activities that can be attributed to the enterprise's CSR. These are: the elimination of extreme hunger and poverty; promotion of education; promotion of gender equality and women's empowerment; reducing infant mortality and improving maternal health; the fight against the human immunodeficiency virus, acquired immunodeficiency syndrome, malaria and other diseases; ensuring ecological sustainable development; improvement of professional skills; assistance in the development of social projects; contribution to the National Assistance Fund or the Prime Minister created by the central government or state governments for socio-economic development and assistance and funds for the well-being of caste, tribes, other classes, minorities and women, etc.

An important part of this law is Clause 4 of Article 135, which stipulates that the Council of each company specified by law must approve the Corporate Social Responsibility Policy for the company and disclose the contents of such Policy in its report, as well as place it on the company's website (India: Corporate Social Responsibility).

The CSR Annual Report includes information on CSR policies, with mandatory reference to web pages of CSR projects and programs; structure of the CSR Committee; average net profit for the last three fiscal years; planned costs for CSR; detailed information about the money spent on CSR during the fiscal year; the amount is not spent, if any, its causes (if the company cannot spend the minimum necessary expenses, the company should indicate the reasons in the report of the non-compliance, so that no penalties were fixed.); the direction in which the amount spent during the fiscal year (Ronald, 2014; India: Corporate Social Responsibility).

Conducting reforms in India has faced many problems, which are explained by the country's heritage: companies began to reduce their profits so as not to make charitable deductions, and the high level of corruption does not allow for the full development of CSR. In this, we see the similarity with the Ukrainian present, but taking into account these facts will make 
possible to make a more effective mechanism of SERE in our country.

\section{Directions of development of SERE in Ukraine}

Considering the experience of 4 countries that occupy a significant place in the modern business world, some suggestions can be made for Ukraine, which will help to create a solid system of socio-economic responsibility in the country.

The main elements of the Swedish model that can be proposed for our country are as follows:

1. Obligatory social reporting for all large enterprises operating in Ukraine. This applies both to foreign companies and to Ukrainians by origin.

2. Government support for explanatory work with entrepreneurs on the importance of implementing and expanding socio-economic responsibility at the enterprise.

3. Study of Swedish legislation in the field of CSR will be a solid basis for its regulation in Ukraine, and namely, the principles, standards, and level of state interference in the regulatory process.

The United States is an economic leader in the world and, of course, can be an example for our country in the field of regulation of SERE. We can highlight the following elements of this model:

1. The orientation of entrepreneurs to philanthropy. To inform about the benefits of the implementation of SERE, the main advantages for the community.

2. Provision of preferential taxation for entrepreneurs who carry out CSR activities and have real results for the community and the state.

3. Determination of the main group of stakeholders as a society, that is, entrepreneurs need to reorient not to the fact that the implementation of SERE brings an increase in profits, but what it gives to society in general. The main objective of SERE is to increase the welfare of the population.

The American model is an effective mechanism, but there is a little role of the state in implementing the CSR; most of it is assigned to enterprises, which in Ukraine cannot be applied now, as then domestic entrepreneurs focus only on making a profit. And at this stage of development of our state, strict regulation is required from the government. In these circumstances, the experience of China and India becomes an occasion.

An example of China for our country is also useful given the similarity of the historical heritage of the economic system. Like in our country, CSR is generally based on already existing labour legislation, but development is getting the same, as China is now in the economic space. Useful for Ukraine can be distinguished as follows:

1. Fixing the obligation of social reporting of stateowned enterprises and giving them a general presiding role in the implementation of CSR. That is, they are becoming an example for others.

2.Adoption of new and improved existinglegislation that regulates employees' rights, gender equality, production standards and product quality, environmental protection.

Indian experience is interesting enough because of the innovative idea to move away from the arbitrariness of CSR and to introduce charity commitment to enterprises that have reached a certain level of profit. For Ukraine, one can distinguish the following, which can be implemented by the government:

1. To establish the conscientiousness of charitable activities for enterprises with a certain level of profit.

2. The obligation to approve the corporate social responsibility policy for these enterprises.

3. Taking into account the negative experience of reforms in India and the implementation of a monitoring system for compliance with the curtain.

Thus, the proposed measures can create a solid mechanism of socio-economic responsibility in Ukraine.

\section{Conclusions}

The taken theoretical assessment showed the basic measures of state for the development of CSR. It becomes clear that the countries that actively develop their economy and gain momentum in the global arena are increasingly focused on the implementation of the latest methods for business and society development. But the analysis showed a difference in the policies of each of the states. Sweden, for example, is distinguished by the fact that the state is focused on the adoption and approval of the laws regulating the sphere of CSR, as well as the Government conducts a series of measures to disseminate the knowledge of the importance of this practice. While in the United States, the level of state intervention is moderate and there is a tendency to delegate tasks to the level of enterprises, although there are tax breaks. The level of social consciousness of US entrepreneurs is high, as they are recognized philanthropists and focused on improving the welfare of society, the introduction of ethical codes in their activities.

Characteristic of China is the "Harmonized Society", which regulates the CSR by the state. Taking into account the international activity of the country, it increasingly focuses on world standards and improves the quality of products and life of the population. In addition, China increases the role of state-owned enterprises in the implementation of CSR.

But the most prominent for researchers in this field is the experience of India, which was the first in the world to withdraw from voluntariness and legally enforce the obligation of charity for large enterprises with a certain level of profit. Although it has gained resistance inside 
the country, it remains the only supporter and deserves careful study.

For Ukraine, the experience of all these countries is beneficial and each of them has certain results that can be applied in our realities, and namely: consolidation of the obligation of the social report, improvement of the national legislation, introduction of an effective system of taxation, government's activities on informing entrepreneurs regarding the importance of implementing the SERE. All this will help create an effective mechanism for the effective socio-economic responsibility of entrepreneurship in Ukraine.

\section{References:}

Sweden leads by example in corporate responsibility. Facts about Sweden. (2011). Swedish Institute. Retrieved from: www.sweden.se.

The Swedish Government policy for corporate social responsibility. Fact sheet. (2016). Ministry of Enterprise and Innovation. Retrieved from: www.government.se.

Overview of CSR developments at a national level. (2013). CSR Committee. Issue 1. Retrieved from: http:// www.ccbe.eu/fileadmin/speciality_distribution/public/documents/CSR/CSR_Position_papers/EN_ CSR_20130131_Overview-of-CSR-developments-at-a-national-level.pdf.

Kolosok, A. (2015). Teoretychnyi aspekt sotsialnoi vidpovidalnosti biznesu [The theoretical aspect of the social vision of business]. Ekonomichnyi chasopys Skhidnoievropeiskoho natsionalnoho universytetu imeni Lesi Ukrainky. [Economic Journal of the East European National Lesia Ukrainka University]. \# 4, pp. 64-67.

Forte, A. (2013). Corporate Social Responsibility In The United States And Europe: How Important Is It? The Future Of Corporate Social Responsibility. International Business \& Economics Research Journal, Volume 12, Number 7. Retrieved from: https://www.researchgate.net/publication/297754923_Corporate_Social_Responsibility_In The United States And Europe_How Important_Is_It The Future_Of Corporate_Social Responsibility. Cecil, Lianna (2008). Corporate Social Responsibility Reporting in the United States, $\bar{M} c$ Nair $\overline{\text { Scholars Research }}$ Journal: Vol. 1: Iss. 1, Article 6. Retrieved from: http://commons.emich.edu/mcnair/vol1/iss 1/6.

Buhmann, K. (2005). Corporate Social Responsibility in China: Current Issues and Their Relevance for Implementation of Law. The Copenhagen Journal of Asian Studies, 22, pp. 62-91. Retrieved from: http://ej.lib. cbs.dk/ index.php/cjas/article/view/521/551.

CSR Asia (2016). A study on corporate social responsibility development and trends in China. Embassy of Sweden, Beijing. Retrieved from: http://www.csr-asia.com/report/CSR-development-and-trends-in-China-FINALhires.pdf

CSR Frame works in China and the European Union Insights for CSR Workshops, CHINA-EUROPA FORUM'S (June 2010). Retrieved from: http://www.chinaeuropa-forum.net/bdfdoc-1704_en.html.

Mullich, Joe (2009). Corporate Social Responsibility Emerges in China. The Wall Street Journal. Retrieved from: http://online.wsj.com/ad/article/chinaenergy-responsibility.

$\mathrm{V}$ myre usylyvaetsia zakonodatelnoe rehulyrovanye sotsyalnoi otvetstvennosty byznesa [Legislative regulation is intensifying worldwide]. Retrieved from: http://tass.ru/plus-one/4403997.

Handbook on Corporate Social Responsibility in India. PricewaterhouseCoopers Private Limited, 2013.

India: Corporate Social Responsibility - Indian Companies Act 2013. Retrieved from: http://www.mondaq.com/ india/x/366528/Corporate+Governance/Corporate+Social+Responsibility+Indian+Companies+Act+2013.

Ronald, Y. (2014). Legal Framework for CSR in India. Retrieved from: https://www.researchgate.net/ publication/268226026_Legal_Framework_for_CSR_in_India. 